腫瘍特異的に分解される PEG 脂質誘導体を用いた全身投与型腫瘍遺伝子 デリバリーシステムの開発

畠山浩人, ${ }^{*, a, b}$ 秋田英万, $a, b$ 小暮健太朗, $a, b$ 原島秀吉 $a, b$

\title{
Development of a Novel Systemic Gene Delivery System for Cancer Therapy with a Tumor-specific Cleavable PEG-lipid
}

\author{
Hiroto Hatakeyama, ${ }^{*, a, b}$ Hidetaka AKIta, ${ }^{a, b}$ Kentaro Kogure, ${ }^{a, b}$ and Hideyoshi Harashima \\ ${ }^{a}$ Graduate School of Pharmaceutical Sciences, Hokkaido University, Kita 12 Nishi 6, Kita-ku, Sapporo \\ 060-0812, Japan, and ${ }^{b}$ The Core Research for Evolutional Science and Technology (CREST), \\ Kawaguchi Center Building, 4-1-8 Honmachi, Kawaguchi City 332-0012, Japan
}

(Received June 14, 2007)

\begin{abstract}
For successful cancer gene therapy via intravenous administration, it is essential to optimize the stability of carriers in the systemic circulation and the cellular association after the accumulation of the carrier in tumor tissue. However, a dilemma exists regarding the use of poly (ethylene glycol) (PEG), which is useful for conferring stability in the systemic circulation, but is undesirable for the cellular uptake and subsequent processes. We report the development of a PEGpeptide-lipid ternary conjugate (PPD). In this strategy, PEG is removed from the carriers via cleavage by a matrix metalloproteinase (MMP), which is specifically expressed in tumor tissues. An in vitro study revealed that the PPD-modified gene carrier (multifunctional envelope-type nano device, MEND) exhibited pDNA expression activity that was dependent on the MMP expression level in the host cells. In vivo studies further revealed that the PPD was potent in stabilizing MEND in the systemic circulation and facilitating tumor accumulation. Moreover, the intravenous administration of PPD or PEG/PPD dually modified MEND resulted in the stimulation of pDNA expression in tumor tissue, as compared with a conventional PEG-modified MEND. Thus MEND modified with PPD is a promising device with the potential to make in vivo cancer gene therapy achievable.
\end{abstract}

Key words_ _ systemic gene delivery; cleavable PEG system; cancer gene therapy; multifunctional envelope-type nano device (MEND); matrix metalloproteinase

\section{1. はじめに}

遺伝子治療は，様々な疾患に対してその原因とな る異常を遺伝子レベルで修復・正常化することによ り根本的な疾患の治療が期待できる医学療法であ り, 今後必要不可欠な治療法になると期待されてい る. 当初は先天的な遺伝子欠損や異常による疾患が 対象であったが, 現在ではがんやアルツハイマー, エイズなどの後天的な難治性疾患の治療の 1 つとし て遺伝子治療の研究が進められており, 臨床応用さ れた遺伝子治療の $66 \%$ はがん治療である1)ことか ら，がん治療への実用化に大きな期待が寄せられて

a北海道大学大学院薬学研究院（干060-0812 札幌市北 区北 12 条西 6 丁目), $b$ 科学技術振興機構（干332-0012 川口市本町 4-1-8 川口センタービル)

*e-mail: hiroto@pharm.hokudai.ac.jp 本総説は, 日本薬学会第 127 年会シンポジウムSD1 で 発表したものを中心に記述したものである.
いる.

遺伝子はそのままの形で投与しても, ヌクレアー ゼなどによりすぐに分解を受け，生体内では不安定 である。したがって，臨床応用例の約 $80 \%$ は，遺 伝子導入システム（ベクター）を用いて行われてい る.1）従来用いられてきたウイルスベクターは，遺 伝子導入効率が高いものの, 臨床試験において死亡 例が報告され, ${ }^{2,3)}$ 免疫原性や毒性の問題がクローズ アップされている.つまり, 遺伝子治療の臨床応 用，特に全身性の投与の成否を握るのは安全性に優 れ遺伝子導入効率の高い非ウイルスベクターの開発 にあると言っても過言ではない.

そこで，本稿ではがんを標的とした全身投与型人 工ベクターの研究開発について，「PEG のジレンマ」 （後述）を解決するためのわれわれの戦略や現在ま での取り組みについて紹介する. 
2. 多機能性エンベロープ型ナノ構造体 (MEND)

遺伝子を薬として用いて薬効を発揮させるには, 核酸をべクターに搭載し，それを投与部位から標的 臓器や組織に送達させるだけでは十分とは言えな い。これは核酸のような水溶性高分子は，細胞膜を 透過することができないためである。したがって， 核酸が機能を発揮する場所である標的細胞の中に取 り込ませ，さらには核にまで送達させる必要があ る。つまり，人工ベクター開発では，投与部位から 標的組織までの体内動態や，その後の標的細胞の核 への送達という細胞内動態の両者に係わる様々なバ リアを突破させることが重要となる．このように， ベクター開発の前に存在するいくつものバリアを突 破するために多くの機能性素子が開発されており, それらを組み込んだ機能性ベクターの構築が試みら れている．しかしながら，いくつもの機能素子を 1 つのベクターに搭載し，かつそれらが必要な場所や 時間に効率よく機能を発揮できるようなべクターの 構築技術は確立されていない.

そこでわれわれは理想的な多機能性ベクターを構 築することを目的として，多機能性エンベロープ型 ナノ構造体 (multifunctional envelope-type nano device; MEND）の開発を行っている（Fig. 1). ${ }^{4)}$ MEND はプラスミド DNA など核酸とポリカチオ ン複合体をコアが脂質エンベロープ膜によって内封 された構造を有している。コアとエンベロープには 特異的リガンドや，血中滞留性素子，また細胞内動 態制御素子など多種類の機能性素子を，トポロジー

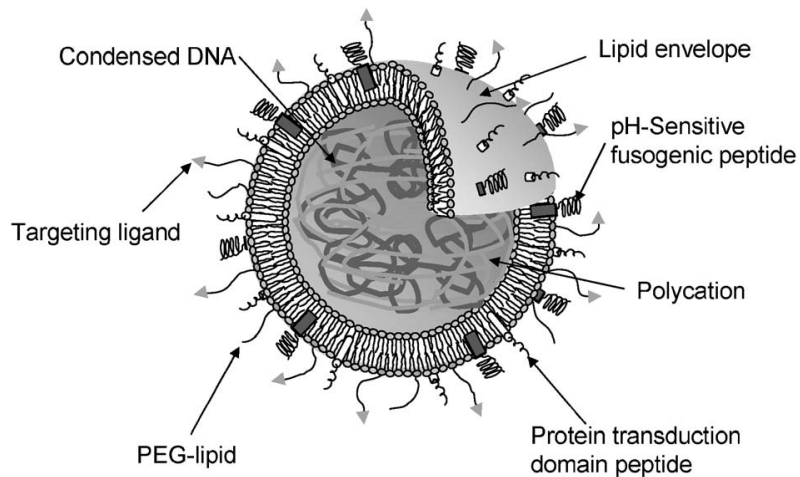

Fig. 1. Schematic Representation of MEND

MEND particles consist of condensed DNA and a lipid envelope containing functional devices including a protein transduction domain peptide that increases intracellular availability, and fusogenic lipids that enhance endosomal escape and facilitate delivery of DNA to the nucleus, and PEGlipids that improve stability in the systemic circulation.
を考慮して配置することが可能である. HIV の Tat ペプチドに由来した膜融合性ペプチドであるアルギ ニン 8 重合体 $(\mathrm{R} 8)^{5)}$ を MEND の表面に修飾する ことにより，R8-MEND は in vitro 培養細胞で高い 遺伝子発現を有している.4,6) これは，R8-MENDが マクロピノサイトーシス経路で細胞へ導入されるた めエンドソーム/リソソームによる分解を受け難 く，また細胞質への脱出も容易なためと考えられ る. ${ }^{6)}$ ベクターが細胞内へ取り込まれる経路はいく つかある7が，細胞内動態の制御による取り込み経 路の選択も遺伝子発現効率の向上には重要な要素で ある.

\section{MEND のがんへのデリバリーと「PEG のジ} レンマ」

リポソームの表面を水溶性高分子であるポリエチ レングリコール（PEG）で覆った PEG 化リポソー ムは, 表面に水和層が形成され細網内皮系 (reticuloendothelial system, RES) に取り込まれ難 く，血中に長時間循環滞留する特性を有してい

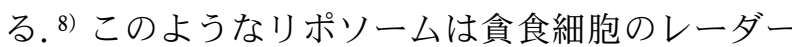
から逃れることから，ステルスリポソーム (STEALTH ${ }^{\circledR}$ lipospme）と呼ばれている。またス テルスリポソームのサイズを $100 \mathrm{~nm}$ 前後に制御す ると, EPR 効果 (Enhanced permeability and retention effect) ${ }^{9)}$ により腫瘍組織に集積することが知ら れている。したがって，全身投与による腫瘍組織へ のベクターの送達には PEG の修飾が有用である.

PEG を修飾した MEND（PEG-MEND）におい ても，サイズを 100-200 nm に制御し静脈から投与 すると，PEG 修飾濃度依存的に滞留性の向上が確 認された（Fig. 2)。一方，PEG-MEND を in vitro 培養細胞に遺伝子導入したところ，PEG 未修飾 MEND と比較して，遺伝子発現活性が著しく低下 することが明らかとなった（Fig. 2)。これはPEG による水和層の形成が，MEND と細胞膜との相互 作用が低下し，細胞への取り込みやエンドソーム脱 出といった細胞内動態が阻害された結果であると考 えられる。つまり，PEGの修飾は体内動態を考え た場合には必要であるが，細胞内動態制御の観点か らはむしろ邪魔であり，「PEGのジレンマ」とも言 うべき問題が生じてしまう。この問題も，体内動態 と細胞内動態の両方を制御しなければならない遺伝 子ベクター開発の高いハードルの 1 つと言える. 


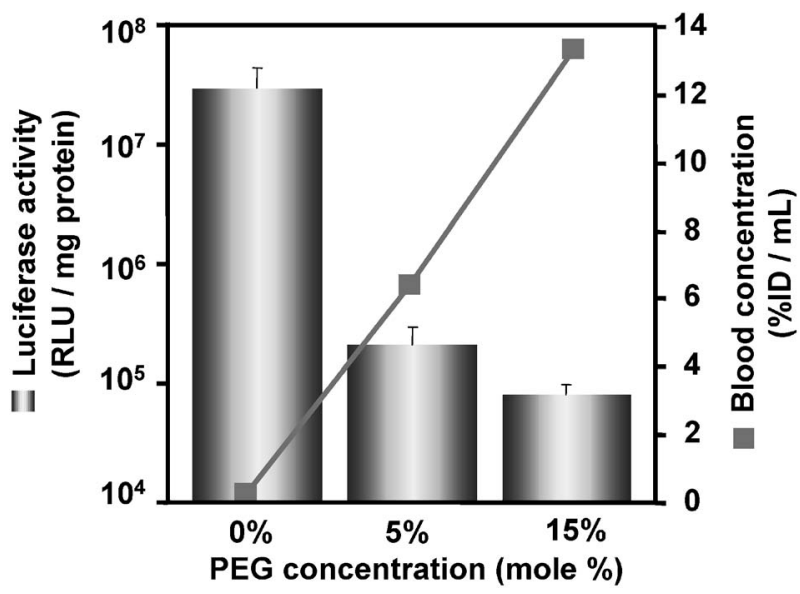

Fig. 2. PEG Dilemma

The surface modification of gene carriers with PEG enhances stability in systemic circulation and accumulation in tumor tissue via EPR effect. In contrast, once the carriers are taken up by the tumor tissue, the PEG inhibits interactions between the carriers and the tumor cells, which results in a significant loss in transfection activity.

そこで，がんを標的としたベクター開発において このような問題を解決するためにわれわれがこれま でに取り組んできた研究成果について紹介する.

\section{PEG のジレンマの解決の戦略}

PEG のジレンマを, PEGの切断によって克服し ようとする研究が行われている。ポリカチオンやカ チオン性脂質を用いた遺伝子ベクターは，一般にエ ンドサイトーシスによって細胞内へ取り込まれてい

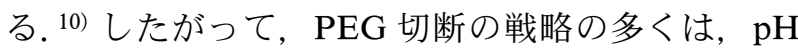
の変化や還元環境，特異的酵素といつた，細胞内の 環境変化を PEG の切断の引き金として利用する研 究が多く見受けられる.

Thompson らは脂質の間にビニル結合を挿入した PEG 脂質誘導体を合成することにより，エンド ソーム内の $\mathrm{pH}$ の変化を利用した PEG の切断を報 告している. ${ }^{11)}$ Szoka らは，ジオルトエステル結合 を挿入することにより $\mathrm{pH}$ 応答性 PEG 脂質を構築 している. ${ }^{12)}$ Wagner らは，ポリエチレンイミンと PEGの間にヒドラゾン結合を挿入し，また上皮成 長因子を標的としたリガンド修飾リポプレックスに より, in vivo 腫瘍組織における遺伝子発現活性の 向上に成功している. ${ }^{13)}$ また, Zalipsky らは細胞内 の還元環境を利用した PEG 切断のために, PEG と 脂質の間にジスルフィド結合を挿入した PEG 脂質 誘導体を構築している. ${ }^{14)}$ Allen らのグループは, 細胞内に存在するタンパク分解酵素であるカテプシ
ン $\mathrm{B}$ により特異的に切断されるペプチドスペー サーを有する PEG 脂質誘導体によって, 細胞内で PEG の切断を報告している. ${ }^{15)}$

われわれは，PEG ジレンマ解決の手段として腫 瘍特異的に発現が充進しているマトリックスメタロ プロテアーゼ（MMP）に着目した。 MMP は活性 中心に $\mathrm{Zn}^{2+}$ を持つ金属酵素群であり，コラーゲン やフィブロネクチンといった細胞外マトリックス （extracellular matrix; ECM）構成成分に対して分 解活性を有する。がんの浸潤や転移には，がん組織 の ECM 分解や血管新生などが不可欠であるが，そ れらの過程に MMP が関与していることが明らか

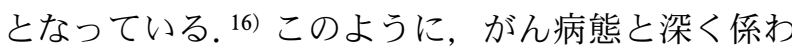
る MMP の分解活性を利用して，われわれは腫瘍 組織に到達した MEND から PEG を酵素的に切り 離してしまおうと考えた（Fig. 3).17) 通常，PEG は脂質誘導体として，脂質部分がリポソームの脂質 膜表面に埋め込まれる形で修飾される．MMPによ り分解されるぺプチド配列が同定されており, ${ }^{18)} こ$ の配列を PEG と脂質の間にリンカーとして挿入し た PEG 脂質誘導体（PPD）を開発した。本素子を MEND に修飾することにより（PPD-MEND），全 身投与された PPD-MEND は EPR 効果で腫瘍組織 に蓄積したのち、MMP によって PEGが切断され, MEND が活性化されるという戦略を立てた。この 戦略は先に紹介した環境応答的な PEG の切断に分 類されるが，遺伝子べクターにおける PEG 切断の 場所が “細胞の外”であるという点では，世界初の 試みである。

\section{PPD の合成と MMP による切断}

このような戦略を実現するために，始めに PEG 脂質誘導体 PPD の合成を行った，PPDの合成は Fig. 4 (a)に示すスキームに従い，PEG 末端の活性 エステル基と MMP 基質ペプチドの $\mathrm{N}$ 末端を結合 させたのち，ペプチドの C 末端と 1,2-dioleoyl-snglycero-3-phosphoethanolamine (DOPE) の一級ア ミンとを結合させることにより行った．MMP の基 質となるぺプチドは，主に MMP-2やMMP-9で切 断を受けるものを用いた。 ${ }^{18)}$ MALDI-TOF MS によ る分子量分析では，ペプチドやDOPE の結合によ り, PEG 由来の分子量分布が理論值とほぼ同等に 増加することが確認された（(1) $M_{n}=3268, M_{\mathrm{w}} /$ $\left.M_{\mathrm{n}}=1.01 ，(2) M_{n}=3955, M_{\mathrm{w}} / M_{\mathrm{n}}=1.01\right)$ 。また ${ }^{1} \mathrm{H}$ 
NMR による構造解析によって，PEG やペプチド， DOPE 由来のシグナル強度から算出されたモル比 が同等であったことから，PPD 合成の確認を行っ

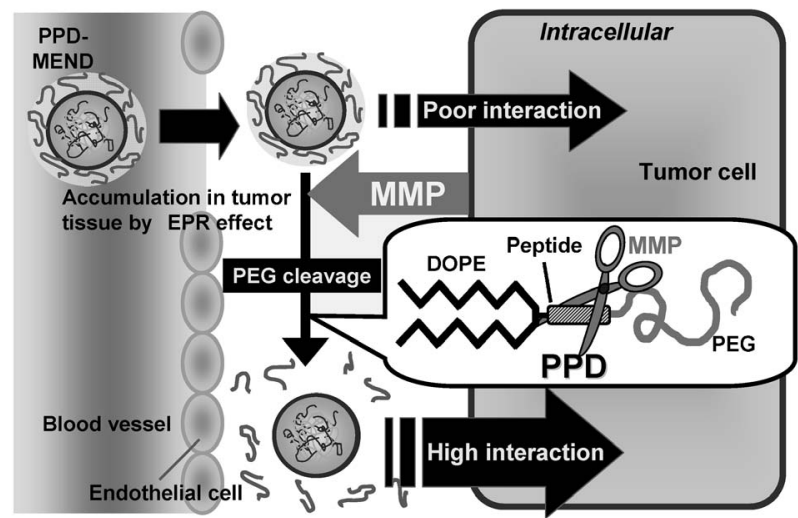

Fig. 3. A Schematic Diagram Illustrating the Strategy Used to Resolve the Dilemma Aassociated with the Use of PEG

i) By modifying the gene carrier with PPD, the systemic circulation is prolonged, and the accumulation in tumor is increased by the EPR effect. ii) After extravasation from capillaries in the tumor tissue, the PPD is cleaved by an extracellular MMP secreted from tumor cells. iii) PEG dissociates from the gene carrier, and the naked carrier can then associate efficiently with the tumor cell surface.
た (Fig. 4(b)).

この PPDを MMP-2 によって処理すると PEG 由来の分子量が減少することを確認した（MMP-2 処理前 : $M_{n}=3953$, MMP-2 処理後: $\left.M_{n}=1980\right)$. また構成脂質として DOPE を用いたリポソームに よる PPD の切断評価を行った。両親媒性脂質であ る DOPE は疎水部が親水部よりも大きいという構 造から，水中では逆へキサゴナル構造を取り凝集す る $(>1000 \mathrm{~nm})$.この DOPE に PEG を修飾する と, 安定なラメラ構造を構成しリポソームとなるこ とが知られている. ${ }^{19)}$ DOPE と PPDを用いた場合 にも, $150 \mathrm{~nm}$ 程度の分散安定なリポソームを形成 するが，この PPD 修飾リポソームを MMP-2 で処 理すると，MMP-2 濃度依存的な粒子径の増大，凝 集（>2000 nm）が観察された（Fig. 4(c)). 一方, $\mathrm{PEG}$ 修飾リポソームでは粒子径の増大はみられな かった (Fig. 4(d)). このことは，PPD 修飾リポ ソームにおいて，MMP-2 によるペプチドの分解と PEGの切断が起こつた結果，安定にリポソームが 形成できなくなり逆へキサゴナル構造となり，粒子 a

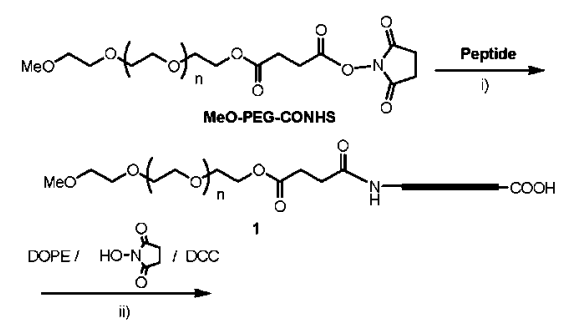

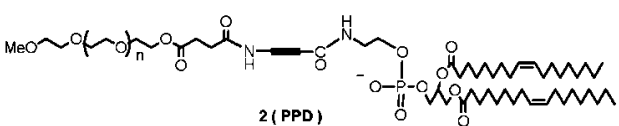

C

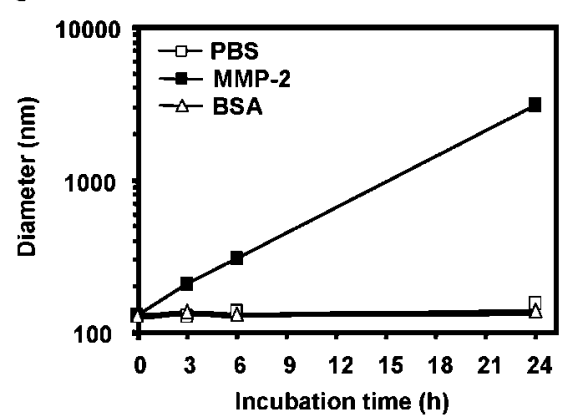

b

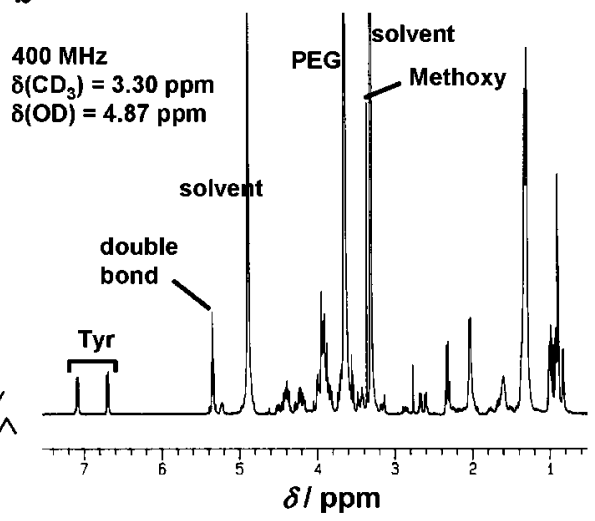

d

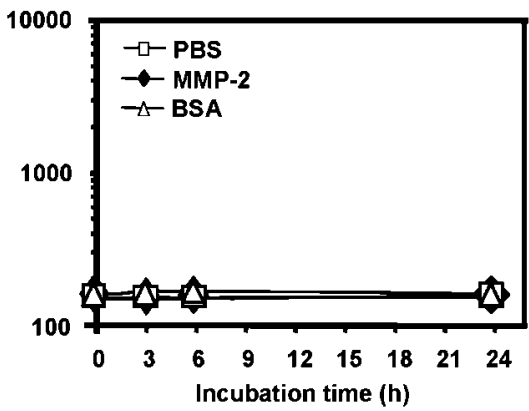

Fig. 4. PPD Synthesis and Cleavage Assay

(a) Synthetic route to PPD i) $\mathrm{Et}_{3} \mathrm{~N}$ (2 eq.), DMSO, 3 h, Y. 95\%; ii) NHS (2 eq.), DCC (2 eq.), $\mathrm{Et}_{3} \mathrm{~N}$ (2 eq.), $\mathrm{CHCl}_{3}, 24$ h, Y. $40 \%$. (b) ${ }^{1} \mathrm{H}$ NMR spectrum of the purified PPD. The liposomes were modified with $10 \mathrm{~mol} \%$ PPD (c) and conventional PEG-lipid (d). PPD-liposomes and PEG-liposomes were treated with MMP-2 or BSA $(56 \mathrm{nM})$ at $37^{\circ} \mathrm{C}$, and the diameters were measured at 3,6 and $24 \mathrm{~h}$ by dynamic light scattering (DLS) measurement. 
径が増大したものと考えられる。

以上のことから，PPD はそれ自体，またリポ ソームのようなキャリアに修飾された状態で, MMP を介して PEGが切断されることが示唆され た.

\section{In vitro における PPD-MEND の機能評価}

MEND のコアは，ルシフェラーゼをコードする plasmid DNA をプロタミンにより凝縮化させるこ とにより $100 \mathrm{~nm}$ 以下で負電荷のものを調整した. また脂質膜はカチオン性脂質である 1,2-dioleoyl-3trimethylammonium-propane (DOTAP) と DOPE, Cholesterol（モル比 $3: 4: 3$ ） から構成し, PEGDSPE 若しくはPPDを $5 \mathrm{~mol} \%$ 修飾した。 MEND はPEG やPPD を修飾することによって，粒子径 が 100-200 nm となり（Table 1)，また電子顕微鏡 により球形のパーティクルとなることが確認された （Fig. 5 (a). ${ }^{17)}$ MMP 産生の盛んなヒ卜線維芽肉腫 由来 HT1080 細胞へ PPD-MEND を遺伝子導入す ると, 従来の PEG-MEND に比べるとルシフェ

Table 1. Physical Properties of MEND, PEG-MEND, PPDMEND

\begin{tabular}{lccccc}
\hline \hline & \multicolumn{3}{c}{ PEG-MEND } & \multicolumn{2}{c}{ PPD-MEND } \\
& MEND & $5 \%$ & $15 \%$ & $5 \%$ & $15 \%$ \\
\hline Diameter (nm) & 281 & 156 & 137 & 162 & 141 \\
-Poteintioal (mV) & 48 & 13 & 7.6 & 19 & 12 \\
Polydispersity index & 0.27 & 0.16 & 0.14 & 0.20 & 0.17 \\
\hline
\end{tabular}

ラーゼの発現活性が約 40 倍上昇した（Fig. 5(b)). 一方, MMP 産生の少ないヒト腎臟内皮様由来 HEK293 細胞では発現の上昇はほとんどみられなか った。しかし，培地中に MMP-2 を添加すると HEK293においても発現活性の上昇がみられた (Fig. $5(\mathrm{~b})$ )。このことから，PPD-MEND は in vitro 培養細胞で MMPを介した PEG の切断によ り，遺伝子発現活性を上昇させることを明らかとし た.

\section{In vivo における PPD-MEND の機能評価}

脂質膜を ${ }^{3} \mathrm{H}$ によりラベル化した PPD-MENDを マウス尾静脈より投与したのち，血中濃度を測定し た（Fig. 6(a)）。PPD-MEND の血中濃度推移は PEG-MEND には劣るものの, PEG 未修飾 MEND と比較すると有意に高いことから，PPD 修飾 MEND は血中滞留性を有することが明らかとなっ た。 HT1080を背部皮下に移植した担がんマウスへ PPD-MEND を投与後 24 時間における腫瘍への移 行量を評価したところ，血中滞留性依存的な移行が 観察されたことから，PPD-MEND は EPR 効果に よって腫瘍へ移行していることが示唆された（Fig. 6(b) ).

また，担がんマウスへ PPD-MENDを投与し， 48 時間後の腫瘍組織におけるルシフェラーゼ発現 量を評価した。 $5 \%$ 修飾 PEG-MEND と $15 \%$ 修飾 PPD-MEND では，腫瘍への移行量がほぼ同程度で あったにも係わらず，PPD-MEND の遺伝子発現量

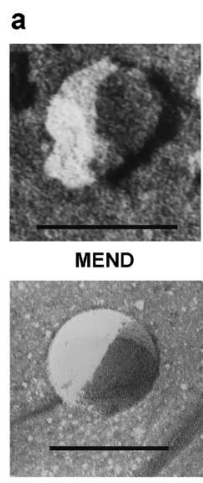

PEG-MEND

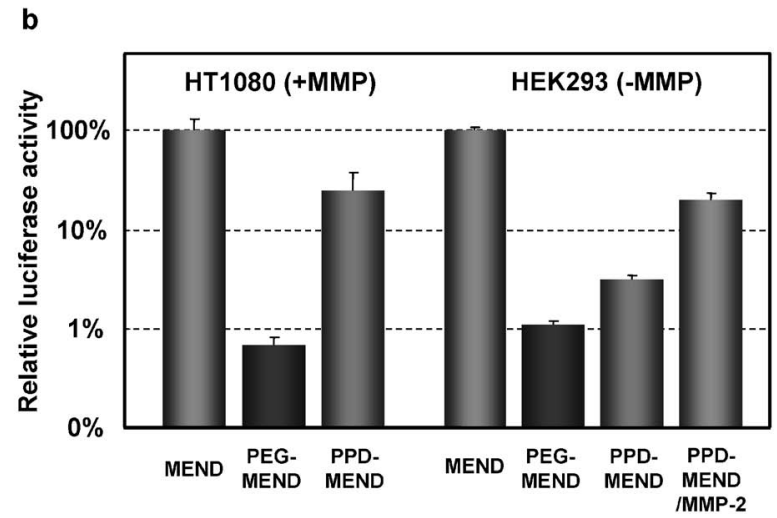

Fig. 5. The Freeze-fracture Electron Micrographs and the In vitro Transfection Activities of PPD- or a Conventional PEG-lipid Modified MEND

(a) The MEND and PEG-MEND were separated from the empty vesicles by discontinuous sucrose density gradient, and then was visualized by freeze-fracture electron microscopy. The bars indicate $200 \mathrm{~nm}$. (b) Luciferase activities of MEND, PEG-MEND and PPD-MEND in HT1080 cells and in HEK293 cells were evaluated at $48 \mathrm{~h}$ after transfection. Transgene expression in HEK293 cells was evaluated after addition of MMP-2 protein in the culture medium at an equal concentration to HT1080, represented as PPD-MEND/MMP-2. Relative luciferase activities are expressed as \% relative light units (RLU) per mg of protein compared to MEND. Each bar represents the mean \pm S.D., $n=3$. 
a
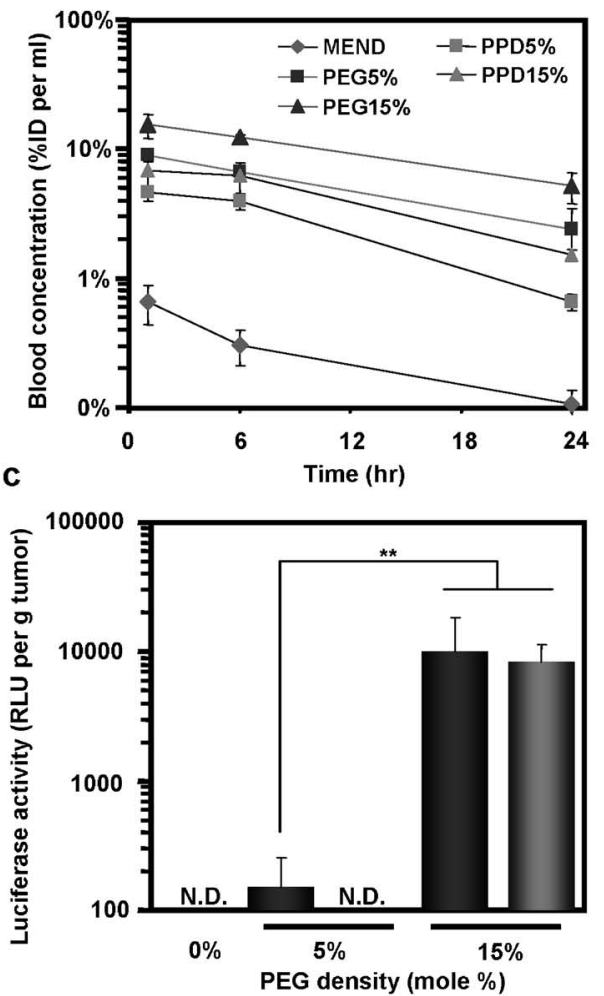

b
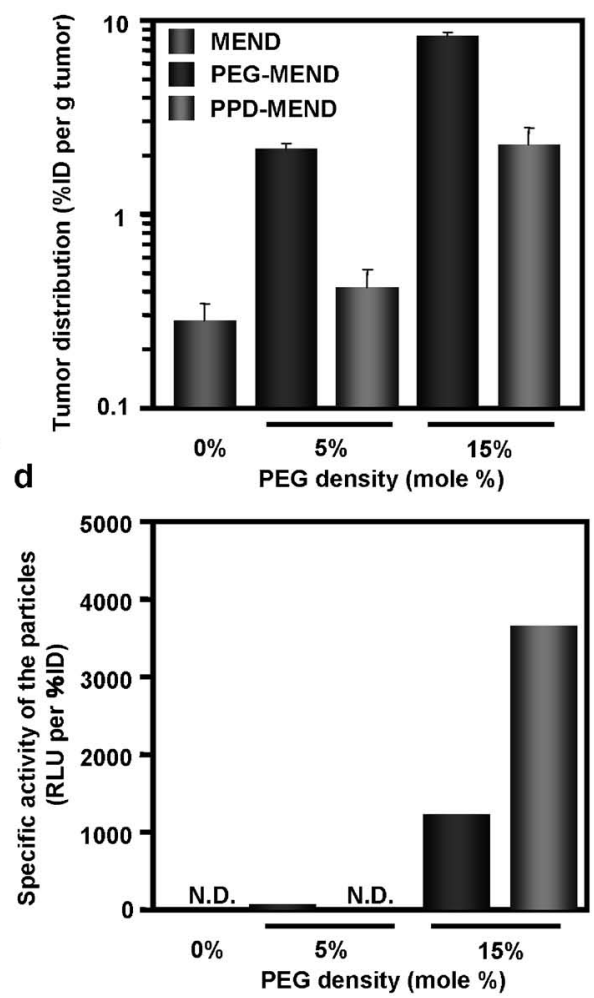

Fig. 6. Stability in Systemic Circulation, the Tumor Distribution and Transfection Activities of MEND In vivo

(a) Blood concentrations of $\left[{ }^{3} \mathrm{H}\right]$ CHE-labeled MEND were evaluated at 1,6 and $24 \mathrm{~h}$ after i.v. injection. Data represent as the \% ID per ml of blood. (b) Tumor distribution of MEND at $24 \mathrm{~h}$ in tumor-bearing mice, expressed as the \% ID per g tumor. (c) Luciferase activity of MEND at $48 \mathrm{~h}$ after i.v. administration of MEND at a dose of $25 \mu \mathrm{g}$ pDNA/mouse, expressed as RLU per g tumor. (d) Specific activity of the MEND in the tumor. Each bar represents the mean \pm S.D., $n=$ 3. ${ }^{* *} p<0.01$. N.D. represents "not detected".

はPEG-MEND と比較して約 55 倍上昇していた (Fig. 6 (c))。また遺伝子発現量を移行量で除し た，移行量当たりの発現活性を評価すると，15\% PPD-MEND は 15\%PEG-MEND よりも高い值を示 した (Fig. 6(d))。 以上のことから，PPD-MEND は腫瘍到達後に，MMPにより PEGが切断された 結果，遺伝子発現活性が上昇することが示唆された。

\section{8. 更なる発現活性の向上}

以上の結果から，PPD を修飾した MEND は静 脈内投与後に腫瘍組織に到達し，MMPを介した PEG の切断と発現活性の向上に成功した。しかし，

PEG と比較すると, PPD の血中滞留性や腫瘍への 移行量が劣ることは否めない。このことは，キャリ アの腫瘍へのデリバリーが前提となる血中投与によ るがん遺伝子治療において，改善しなければならな い課題と言える。われわれはこれまでに，MEND に修飾するPEGのすべてをPPD に置き換えて評 価を行ってきた，そこで，血中滞留性のよい PEG と，遺伝子発現活性に有利な PPD を混合すること
により，体内動態と到達後の遺伝子発現活性の最適 化を試みた。すなわち，総 PEG 修飾密度を 5,15 , $20 \mathrm{~mol} \%$ とし, PEG とPPDを 1：1 で MEND に 修飾した PEG/PPD-MEND の遺伝子発現活性を評 価した。PEG-MEND では腫瘍移行量，遺伝子発現 量はともに $15 \%$ で最大であったのに対して，PEG/ PPD-MEND では $20 \%$ で最大であった（Fig. 7 (a))。ほぼ同等な腫瘍移行量を示した修飾量 $20 \%$ では，遺伝子発現量は 60 倍と大きく上昇すること が示された（Fig. 7(b))。このことは，体内動態と 細胞への取り込みの両方が改善された結果であると 考えられる。

以上のことより，in vivo 腫瘍を標的とした血中 投与型遺伝子キャリアの設計には，血中滞留性や腫 瘍への移行といつた体内動態だけでなく, 腫瘍送達 後の細胞内動態の両方を精密に制御する必要性があ ることを示唆している.

\section{9. 終わりに}

われわれは腫瘍で過剰発現している MMPによ 
a

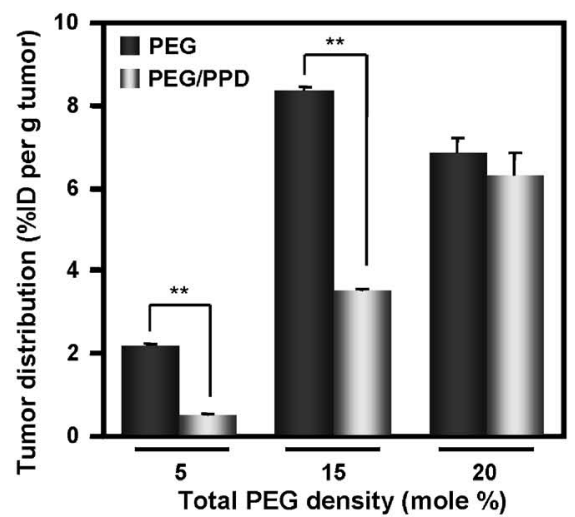

b

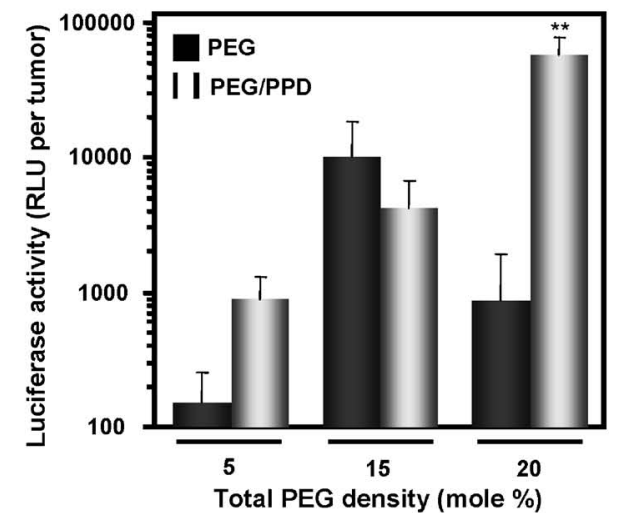

Fig. 7. Further Evaluation of the Transfection Activities of MENDs in the In vivo Tumor

The MEND was modified with PEG and PPD (1:1 mole ratio) at 5, 15 and 20\% total PEG densities. (a) Tumor distribution of MENDs at $24 \mathrm{~h}$ in tumorbearing mice, represented as the \% ID per g tumor. (b) Luciferase activity of MENDs at $48 \mathrm{~h}$, expressed as RLU per g tumor. Each bar represents the mean \pm S.D., $n$ $=3 .{ }^{*} p<0.01$.

る PEG の切断により遺伝子ベクターの発現活性を 向上させることに成功した。しかし，実際の臨床に 応用するためには，更なる発現効率の上昇が求めら れる，今後，発現活性の向上を目指した研究を行っ ていく際には，遺伝子 1 コピー当たりの発現効率を 更に上昇させることが必要である．われわれは細胞 内動態制御，その中でも特に核膜の突破の観点から 開発を進め, 安全かつウイルスベクターに匹敵する 人工ベクターを創製し，遺伝子治療の基盤技術の確 立，がん治療に貢献したい。

謝辞 PEG 脂質誘導体の合成に当たり, 有益 なご助言と多大なご指導を頂きました筑波大学学際 物質科学研究センター・長崎幸夫先生（筑波大学学 際物質科学研究センター教授），大石 基先生（同 助教）に深く御礼申し上げます。また電子顕微鏡写 真の取得に関し，ご協力頂いた上野雅晴先生（富山 大学薬学部薬剂設計学教授), 木平孝高先生（同助 教）に，感謝申し上げます。

\section{REFERENCES}

1) The Journal of Gene Medicine, Clinical Trial sites 〈http://www.wiley.co.uk/genetherapy/ clinical/>

2) Lehrman S., Nature, 401, 517-518 (1999).

3) Marshall E., Science, 299, 320 (2003).

4) Kogure K., Moriguchi R., Sasaki K., Ueno M., Futaki S., Harashima H., J. Control.
Release, 98, 317-323 (2004).

5) Futaki S., Ohashi W., Suzuki T., Niwa M., Tanaka S., Ueda K., Harashima H., Sugiura Y., Bioconjug. Chem., 12, 1005-1011 (2001).

6) Khalil I. A., Kogure K., Futaki S., Harashima H., J. Biol. Chem., 281, 3544-3551 (2006).

7) Khalil I. A., Kogure K., Akita H., Harashima H., Pharmacol. Rev., 58, 32-45 (2006).

8) Klibanov A. L., Maruyama K., Torchilin V. P., Huang L., FEBS Lett., 268, 235-237 (1990).

9) Matsumura Y., Maeda H., Cancer Res., 46, 6387-3692 (1986).

10) Lv H., Zhang S., Wang B., Cui S., Yan J., $J$. Control. Release, 114, 100-109 (2006).

11) Shin J., Shum P., Thompson D. H., J. Control. Release, 91, 187-200 (2003).

12) Guo X., Szoka F. C., Bioconjug. Chem., 12, 291-300 (2001).

13) Walker C. F., Fella C., Pelisek J., Fahrmeir J., Boeckle S., Ogris M., Wagner E., Mol. Ther., 11, 418-425 (2005).

14) Zalipsky S., Qazen M., Walker II J. A., Mullah N., Quinn M. Y., Huang S. K., Bioconjug. Chem., 10, 703-707 (1999).

15) Zhang J. X., Zalipsky S., Mullah N., Pechar M., Allen T. M., Pharmacol. Res., 49, 185198 (2004).

16) Coussens L. M., Fingleton B., Matrisian L. M., Science, 295, 2387-2392 (2002).

17) Hatakeyama H., Akita H., Kogure K., Oishi 
M., Nagasaki Y., Kihira Y., Ueno M., Kobayashi H., Kikuchi H., Harashima H., Gene Ther., 14, 68-77 (2007).

18) Turk B. E., Huang L. L., Piro P. B., Cantley
L. C., Nat. Biotechnol., 19, 661-667 (2001).

19) Holland J. W., Cullis P. R., Madden T. D., Biochemistry, 35, 2610-2617 (1996). 